\title{
Effect of Planting Patterns and Fertility Levels in Chickpea and Linseed Intercropping in Tarai Region of Uttarakhand, India
}

\author{
Dharmendra Meena ${ }^{1 *}$, Chandra Bhushan ${ }^{1}$, Anil Shukla ${ }^{1}$, \\ V.K. Singh ${ }^{1}$ and Navneet Pareek ${ }^{2}$
}
${ }^{1}$ Department of Agronomy, College of Agriculture, ${ }^{2}$ Department of Soil Science, College of Agriculture, Govind Ballabh Pant University of Agriculture \& Technology, Pantnagar (Uttarakhand)

*Corresponding author

K e y w or d s
Linseed, Chickpea,
Fertility,
Intercropping,
Chickpea equivalent
yield.

Keywords

Linseed, Chickpea,

Fertility,

Intercropping,

Chickpea equivalent yield.

Article Info

Available Online:

\section{A B S T R A C T}

\begin{abstract}
A field experiment was conducted during Rabi season of 2015-16 and 2016-17 at N. E. Borlaug Crop Research Centre of Govind Ballabh Pant University of Agriculture \& Technology, Pantnagar (Uttarakhand) with an objective to find out the appropriate row ratio and nutrient management strategy for chickpea + linseed intercropping system. The experiment was conducted in Split Plot Design with three replications having four main plot treatments (Planting patterns) viz; Sole chickpea, Sole linseed, chickpea + linseed (3:1), chickpea + linseed (4:2), and four Sub plot treatments (Fertility levels) viz., 0:0:0 NPK kg/ha (F1), 20:40:20 NPK kg/ha (F2), 40:40:20 NPK kg/ha (F3), 60:40:20 NPK $\mathrm{kg} / \mathrm{ha}(\mathrm{F} 4)$. The results revealed that the grain/seed, straw/stover and biological yields of both chickpea and linseed were higher in sole cropping than in intercropping combinations. However, the higher chickpea equivalent yield (System Productivity) was recorded in chickpea + linseed intercropping combinations under both the row arrangements (4:2 and 3:1) were found at par with sole chickpea and significantly higher over sole linseed.
\end{abstract}

\section{Introduction}

India is the largest producer $(25 \%$ the of global production), consumer (27\% of the world consumption), and importer (14\%) of pulses in the world. Pulses account for around 20 per cent of the area under foodgrains and contribute around 7-10 per cent of the total foodgrains production in the country. Chickpea (Cicer arietinum) is an important winter season food legume having extensive geographical distribution. In India, it is a major crop covering 8.41 million hectares of area (37\% of the total area under pulses) with 6.68 million tons of production $(47 \%$ of the total pulse production) (FAO, 2016-17). But, there has not been any significant increase in area (7.75 million hectare) under chickpea at national level since 1969-70. The increase in production has mainly been due to increase in 
its productivity from 450 to $794 \mathrm{~kg} \mathrm{ha}^{-1}$ (Chaturvedi and Dua, 2001). To improve the productivity and stability, farmers often grow chickpea in association with various other crops, like barley, mustard, linseed and safflower. Amongst them, chickpea + linseed is one of the most important cropping systems of Central India. Intercropping with linseed had also been found to reduce the incidences of pod borer in chickpea (Ahmed, 2003).

In wake of the ever growing population of the world and India, in particular, the present food base seems to be narrowing down. The problem has been getting further aggravated with the varying patterns in the climate change making it prone to frequent crop failure. The high input based agriculture in present situation is showing signs of stress, and long term cereal based or nutrients exhaustive crops are putting a question mark on long term sustainability (Kalaghatagi et al., 2017). Thus, diversification and intensification of crops and cropping systems, in space as well as time, has become absolutely necessary for tackling this worldwide worrying issue. Therefore, in view of the facts detailed above, the present investigation was carried out to explore the appropriate planting pattern and nutrient management strategy in chickpea + linseed intercropping systems.

\section{Materials and Methods}

A field experiment was conducted during Rabi season of 2015-16 and 2016-17 at N. E. Borlaug Crop Research Centre of Govind Ballabh Pant University of Agriculture \& Technology, Pantnagar (Uttarakhand) to find out the appropriate row ratio and nutrient management strategy for chickpea + linseed intercropping system and to assess the effect of the same on the performance of chickpea and linseed. The soil of the experimental site was silty clay loam in texture and low in available nitrogen $(257.8 \mathrm{~kg} / \mathrm{ha}$ and 269.1$)$ and medium in available phosphorus $(12.4 \mathrm{~kg} / \mathrm{ha}$ and $13.2 \mathrm{~kg} / \mathrm{ha})$ and low in available potassium (177.3 and $175.6 \mathrm{~kg} / \mathrm{ha}$ ) and high in organic carbon $(0.87$ and $92 \%)$ contents with neutral in reaction ( $\mathrm{pH} 7.3$ and 7.36) in 201516 and 2016-17, respectively. The experiment was conducted in Split Plot Design with three replications having four main plot treatments viz; Sole chickpea, Sole linseed; chickpea + linseed (3:1) and chickpea + linseed (4:2), and four Sub plot treatments viz; 0:0:0 NPK kg/ha (F1), 20:40:20 NPK kg/ha (F2), 40:40:20 NPK $\mathrm{kg} / \mathrm{ha}$ (F3), 60:40:20 NPK kg/ha (F4). Chickpea variety 'PG 186' and linseed 'JRF4' were sown in rows $30 \mathrm{~cm}$ apart on 15 December and 28 November during 2015-16 and 2016-17. Nitrogen, phosphorus and potassium doses were applied through NPK mixture (12:32:16) and remaining does of nitrogen was applied through urea were drilled at sowing as per treatments. A total of 22.5 and $18 \mathrm{~mm}$ rainfall was received with 02 and 03 rainy days during 2015-16 and 2016-17 during the crop season.

\section{Results and Discussion}

The sole crop of chickpea and linseed recorded significantly higher grain yield than that of their contributions in the intercropping systems during both the years. Between the two intercropping combinations of chickpea + linseed, 3:1 remained significantly superior over 4:2 in terms of the grain yield of chickpea during both the years, while the trends were reversed in terms of the grain yield of linseed. Superiority of the sole crops of chickpea and linseed over their contributions in intercropping, and the significant variation among the two intercropping systems could be attributed to the more area under the concerned crop as the intercropping was practiced in replacement series. Tanwar et al. (2011); Gan et. al. (2009); Biradar et al. (2015) and Upadhyay et al. (2012) have also expressed similar view in their studies (Table 1 and 2). 
Table.1 Effect of planting pattern and fertility levels on yields of chickpea and linseed during 2015-16 and 2016-17

\begin{tabular}{|c|c|c|c|c|c|c|c|c|c|c|c|c|}
\hline \multirow[t]{3}{*}{ Treatment } & \multirow{2}{*}{\multicolumn{2}{|c|}{$\begin{array}{c}\text { Grain yield }(\mathrm{Kg} / \mathrm{ha}) \\
\text { Chickpea }\end{array}$}} & \multirow{2}{*}{\multicolumn{2}{|c|}{$\begin{array}{c}\text { Seed yield (Kg/ha) } \\
\text { Linseed }\end{array}$}} & \multicolumn{4}{|c|}{ Biological yield (kg/ha) } & \multirow{2}{*}{\multicolumn{2}{|c|}{$\begin{array}{c}\text { Straw Yield (kg/ha) } \\
\text { Chickpea }\end{array}$}} & \multirow{2}{*}{\multicolumn{2}{|c|}{$\begin{array}{c}\text { Stover Yield }(\mathrm{kg} / \mathrm{ha}) \\
\text { Linseed }\end{array}$}} \\
\hline & & & & & \multicolumn{2}{|c|}{ Chickpea } & \multicolumn{2}{|c|}{ Linseed } & & & & \\
\hline & 2015-16 & 2016-17 & 2015-16 & 2016-17 & 2015-16 & 2016-17 & 2015-16 & 2016-17 & 2015-16 & 2016-17 & 2015-16 & 2016-18 \\
\hline \multicolumn{13}{|l|}{ Planting Pattern } \\
\hline Sole Chickpea & 1973 & 2131 & - & - & 5953 & 6279 & - & - & 3980 & 4148 & - & - \\
\hline Sole Linseed & - & - & 916 & 936 & - & - & 2818 & 2848 & - & - & 1901 & 1912 \\
\hline Chickpea + Linseed (3:1) & 1736 & 1892 & 263 & 316 & 5243 & 5548 & 798 & 890 & 3518 & 3656 & 535 & 574 \\
\hline Chickpea + Linseed (4:2) & 1487 & 1615 & 432 & 448 & 4460 & 4742 & 1307 & 1342 & 2977 & 3127 & 876 & 893 \\
\hline SEm \pm & 41 & 49 & 26 & 20 & 103 & 87 & 49 & 54 & 66 & 64 & 27 & 34 \\
\hline CD $(P=0.05)$ & 160 & 192 & 103 & 77 & 405 & 338 & 193 & 211 & 260 & 248 & 107 & 134 \\
\hline \multicolumn{13}{|l|}{ Fertility Level } \\
\hline F1 (0:0:0)NPK & 1297 & 1380 & 292 & 282 & 3959 & 4162 & 898 & 904 & 2662 & 2781 & 606 & 622 \\
\hline F2 (20:40:20)NPK & 1818 & 2006 & 485 & 569 & 5497 & 5936 & 1472 & 1564 & 3685 & 3930 & 985 & 995 \\
\hline F3 (40:40:20)NPK & 1986 & 2117 & 647 & 664 & 5977 & 6161 & 1999 & 2052 & 4007 & 4045 & 1353 & 1388 \\
\hline F4 (60:40:20)NPK & 1827 & 2014 & 723 & 752 & 5441 & 5832 & 2196 & 2253 & 3614 & 3819 & 1472 & 1499 \\
\hline SEm \pm & 40 & 74 & 20 & 14 & 156 & 231 & 46 & 59 & 90 & 151 & 30 & 50 \\
\hline CD $(P=0.05)$ & 119 & 221 & 58 & 41 & 464 & 687 & 136 & 176 & 268 & 448 & 90 & 146 \\
\hline
\end{tabular}

Table.2 Effect of planting pattern and fertility level on chickpea equivalent yield of chickpea and linseed during 2015-16 and 2016-17

\begin{tabular}{|l|c|c|}
\hline Treatment & \multicolumn{2}{|c|}{ Chickpea equivalent yield (CEY) (Kg/ha) } \\
\hline Sole Chickpea & & $\mathbf{2 0 1 6 - 1 7}$ \\
\hline Sole Linseed & 1972 & 2139 \\
\hline Chickpea + Linseed (3:1) & 1373 & 1404 \\
\hline Chickpea + Linseed (4:2) & 2130 & 2366 \\
\hline SEm \pm & 2134 & 2287 \\
\hline CD (P=0.05) & 60 & 44 \\
\hline Fertility Level & 194 & 1396 \\
\hline F1 (0:0:0)NPK & & 2236 \\
\hline F2 (20:40:20)NPK & 1301 & 2428 \\
\hline F3 (40:40:20)NPK & 1909 & 2431 \\
\hline F4 (60:40:20)NPK & 2217 & 40 \\
\hline SEm \pm & 2183 & 117 \\
\hline CD (P=0.05) & 50 & 161 \\
\hline
\end{tabular}


The fertility levels increased the grain yield of chickpea up to 40:40:20 NPK kg/ha (F3), while this increase was significant up to 60:40:20 NPK kg/ha (F4) in case of linseed during both the years. The straw/stover and biological yields biological yield were influenced significantly due to the planting patterns and fertility levels during both the years. The sole crops of chickpea and linseed recorded significantly higher straw/stover and biological yields over the intercropping combinations. Between the two intercropping combinations of chickpea + linseed 3:1, remained significantly superior over $4: 2$ in case of chickpea during both the years, while 4:2 was significantly superior over $3: 1$ in terms of the stover and biological yield of linseed. During 2015-16, 40:40:20 NPK kg/ha (F3) recorded highest straw/stover and biological yields of chickpea during both years. In case of linseed, the highest stover and biological yields were obtained with application of 60:40:20 NPK kg/ha (F4). Tanwar et al. (2011) and Abraham et al. (2010) reported the similar results from Lakhaoti (U.P). The highest chickpea equivalent yield was obtained in chickpea + linseed (4:2) during 2015-16, whereas chickpea + linseed (3:1) recorded highest chickpea equivalent yield during 2016-17. As the fertility levels increased the chickpea equivalent yield was also increased up to 40:40:20 (F3) during both the years. This could be attributed to the higher fertility level which managed to support the combined demand of both the crops at optimum level Singh and Pandey (2002) and Ahalawat and Gangaiah (2010) reported that the chickpea + linseed intercropping performed better over sole chickpea.

\section{References}

Abraham, T., Thenua, O.V.S. and Shivakumar, B.G. 2010.Impact of levels of irrigation and fertility gradients on dry matter production, nutrient uptake and yield on chickpea (Cicer arietinum) intercropping system. Legume Res. 33(1): 10-16.

Ahlawat, I.P.S. and Gangaiah, B. (2010). Effect of land configuration and irrigation on sole and linseed intercropped chickpea. Indian Journal of Agricultural Sciences, 80 (3): 250253.

Ahmed, R. 2003. Insect pests of chickpea and their management. (In:) Chickpea Research in India. Masood Ali, Shiv Kumar and N B Singh (Eds). Indian Institute of Pulse Research, Kanpur, India.

Biradar, S.A., KUMAR, K. A., Rajanna B. and Shubha, G.V. 2015. Economic feasibility of intercropping of linseed (Linum usitatissimum L.) and chickpea under rainfed condition. Green Farming Vol. 6 (3): 601-603; $\quad$ MayJune, 2015.

Chaturvedi, S. K. and Dua, R. P. (2001). Improved varieties of chickpea in India. Indian Institute of Pulses Research, Kanpur, p. 1

FAO database (2016-17). Food and Agriculture Organization Database: http://www.faostat.fao.org.

Gan, Y.T., Warkentin, T. D., McDonald, C. L., Zentner, R. P. and A. Vandenberg (2009) Seed Yield and Yield Stability of Chickpea in Response to Cropping Systems and Soil Fertility in Northern Agric. and Agri-Food Canada. Agronomy Journal. 5 (101): 11131122.

Kalaghatagi S.B., Guggari A.K., Kambreker D.N. and Kadasiddappa, M. 2017. Performance of Linseed Based Intercropping Systems in Different Row Ratio under Semi Arid Region of Karnataka. Indian J. Dryland Agric. Res. \& Dev. 2017 32(1): 26-31

Tanwar, S. P. S., Rokadia, P. and Singh, A. K. 
(2011). Effect of row ratio and fertility levels on the performance of chickpea (Cicer arietinum) and linseed (Linum usitatissimum) intercropping system under rainfed condition. Indian Journal of Agronomy 56 (3): 87-92.

\section{How to cite this article:}

Dharmendra Meena, Chandra Bhushan, Anil Shukla, V.K. Singh and Navneet Pareek. 2018. Effect of Planting Patterns and Fertility Levels in Chickpea and Linseed Intercropping in Tarai Region of Uttarakhand, India. Int.J.Curr.Microbiol.App.Sci. 7(08): 1957-1961. doi: https://doi.org/10.20546/ijcmas.2018.708.225 